Др Лидија Д. Делић

\title{
МЕТАМОРФОЗЕ ЧОВЕКА У ЖИВОТИЬУ
}

Логика трансформација у усменом фолклору*

\begin{abstract}
У раду се на материјалу српског усменог фолклора илуструје логика модификације човека у животињу у спектру жанрова од бајке и предања, до баладе и епике, заснована на особеним типовима фантастике, стратегијама концептуализације и прагматици текста. Прате се смерови трансформације и веза метаморфозе и греха (чуда, еманације трансцендентног), што је основа за реконструкцију позиције и „,потребе“ животиње у антропоцентричном моделу света.

Кључне речи: животиња, анималистика, метаморфоза, чудо, змија, соко, вила, кукавица.
\end{abstract}

1. Претварање човека у животињу и трансформација у супротном смеру фреквентни су у усменим предањима и обимнијим прозним врстама, а у вези су с типовима фантастике карактеристичним за конкретне жанрове и њихову „духовну заокупљеност“ (А. Јолес). Претварање птица у прелепе девојке (,Златна јабука и девет пауница“; В 4), или претварање девојке, дивове кћери, у пчелу, патку и поново у девојку („Царевић и дивова кћи“; Ч 34), змије у јунака („Змија младожења“; В 9, 10) и сл. - један је од основних видова „зачаравања“" и „рашчаравања“ у иницијалним и финалним етапама радње бајке и (без обзира на могућа тотемска, ${ }^{1}$ митска и обредна упоришта) има превасходно сижејну функцију. Привремена метаморфоза стабилан је елемент „у склопу типа о чаробњаковом шегрту“ (у мачка, врапца, коња, голуба), као и у бајкама с мотивом магичног бега (преображаји у овцу, пчелу, патку, голуба и голубицу) (РАдуловић 2009: 204). Трајне метаморфозе човека у животињу ретке су, међутим, у бајкама и ексклузивно су везане за ликове помоћнике

\footnotetext{
* Рад је суфинансирала Хрватска заклада за знаност пројектом „Културна анималистика: интердисциплинарна полазишта и традицијске праксе“ (IP-2019-04-5621).

${ }^{1}$ О тотемским исходиштима бајке детаљније у РАдуловић 2009: 132 и MARJANIĆ 2020: 146-148, где је наведена и референтна литература.
} 
(Пепељугина мајка се претвара у краву; В 32) или за ситуације у којима се у бајке уводе елементи атипични за овај жанр, какав је случај с варијантом „Царева кћи овца“ (В 28), у којој се јавља мотив инцеста. У тој бајци супруга на самрти заклиње мужа да се након њене смрти ожени, али искључиво оном девојком којој ће савршено пристајати њен прстен. Када се након неуспешне потраге по царству испостави да прстен одговара само њиховој кћери и када отац, обавезан супругином самртном жељом, крене да се ожени сопственом кћерком - она се претвара у овцу и остаје уз оца. Овај невешти епилог показује да бајка није умела да изађе на крај са њој страним мотивом инцеста, ${ }^{2}$ типичним за усмене баладе и усмена предања, а решење је повучено из општег фонда традиције, која инцест често доводи у везу с метаморфозама, по правилу у камен. Оно је, међутим, суштински неприлагођено систему бајке, јер се трајна метаморфоза која није последица греха приближава апсурду - ћерка претворена у овцу остаје с оцем у недефинисаном односу и умире када и он: „По том је овца свеђер уз цара скакутала и блејала, и он је њивио и гојио као своје дијете, и кад цар умре, у они дан умре и овца.“

За разлику од бајки, предања трансформацијом, чак и када у етиолошком духу „објашњавају“ порекло животиња, по правилу маркирају грех. Син који с оцем покушава да превари комшију око међе (или брат брата) тако што се закопа у земљу и лажно сведочи где је граница између два имања претвара се у кртицу (МАРковић 2004: 75-77); непослушна кћи претвара се у змију у комплексу прича о закопаном благу (ПАлАВЕСтРА 2003: 135-136), невеста „немкињица“ која годинама служи све укућане без речи и крај које доводе другу, језичаву жену претвара се у ластавицу и напушта дом (ЗлАтковић 2007: 476), пекар који ногама меси хлеб претвара се у медведа ${ }^{3}$ (ЂоРЂЕвић [T.] 1958/I: 253) и сл. ${ }^{4}$ Чак и тамо где је библијско предање понудило своју верзију приче о метаморфози, шира фолклорна традиција инклинирала је наративима о огрешењу. Вук тако бележи предање по коме су се сестре Лазара из Витаније када је он први пут умро заветовале да ће тужити за њим док су живе, па када је Исус подигао Лазара из мртвих створио је и птицу која ће уместо њих кукати - да се одржи завет (CP, s. v. кукавица). ${ }^{5}$

\footnotetext{
${ }^{2}$ Мотив би могао имати упориште у древним праксама везаним за венчање краљева („Инке, стари Персијанци, Египћани, Ирци и Кинези познавали су обичај да се краљ жени кћерком“; РАдуловић 2009: 94), али је у конкретној традицији приповедања дисфункционалан. Како показује Немања Радуловић, у бајци је инцест „одбачен, односно развој догађаја подразумева обрте који онемогућавају грешну везу“ (2009: 87); уп. и САмАРџијА 2011: 124.

3 Исцрпан словенски компаративни материјал о пореклу медведа од човека дат је у ГурА 2005: 118-119.

4 У раду нас занима искључиво трансформација човека у животињу, нећемо се овом приликом бавити бројним метаморфозама демонских бића (вештица, ала, вампира итд.), анђела, светаца и сл. Некрштенци који се трансформишу у демонска зооморфна бића (најчешће птице) такође ће остати ван зацртаних оквира истраживања.

${ }^{5}$ Круг варијаната дат је у ЂорЂЕвић [Д.] 1988: 552. УП. ЧАлКАнОвић 1994/1: 87; ЂорЂЕвић [T.] 1958/II: 3-20.
} 
Често се, међутим, грех неумереног тужења (познат у традицији и у виду несмиреног преминулог детета чија је кошуљица мокра од мајчиних суза) апострофира као узрок претварања сестре у кукавицу (бугарска традиција повезује мотив дугог боловања јунака са тужењем сестре због којег анђели не могу да приђу и узму му душу; СбНУ 10, стр. 15,6 р. 7,8$),{ }^{6}$ а однос према трансформацији и чину превеликог жаљења посредно се ишчитава из чињенице да у предањима овог типа кукавице алтенирају са змијамат:
Св. Јован каже на оне сестре:
- А што кукате? - каже: - Ти, каже, да кукаш на грану, а ти да идеш У трње.
И створи се једна у кукавицу, а једна у змију (ЂоръЕвић [Д.] 1988: 477).

Кардинална разлика међу жанровским стратегијама бајке и предања јесте, међутим, у доминантном смеру трансформације, а ти смерови - са становишта неминовно антропоцентричне културе - ни изблиза нису подједнако оптимални нити пожељни. Бајке фаворизују претварање животиња у људе, или искуство боравка у животињском обличју, као неку врсту авантуристичке катарзе којој следи срећни повратак у нормалу, док предања говоре о трансформацији у супротном смеру, а она се неминовно сагледава као вид казне и фигурира као егземпл и опомена.

2. ЕПСКЕ МЕТАМОРФОЗЕ. Епске и баладичне метаморфозе ослањале су се на сижее бајки и предања сходно сопственим жанровским стратегијама и преокупацијама (Милошевић ЂоръЕвић 1971). Епика је од бајке превасходно баштинила конкретне сижејне обрасце и мотиве, какав је, примера ради, „спољашња душа“ (Детелић 1996: 89). ${ }^{8}$ Бајковна фантастика је, међутим, битно другачија од епске (САмАРџијА 2008: 285), па је и број ових позајмица релативно мали. Бајковити сижеи су само по изузетку били адоптирани у усмену епику, углавном онда када су залеђе давали типови сукоба који одговарају „тешким задацима“ у бајкама (РвоР 1990) или амбивалентна природа

${ }^{6}$ И Вук на другом месту даје варијанту предања: „Србљи приповиједају да је кукавица била жена и имала брата, па јој брат умро и она за њим тако много тужила и кукала, док се није претворила у тицу (једни кажу да се брату досадило њено кукање и јаукање, па је он проклео те се претворила у тицу, а једни опет кажу да се Бог на њу расрдио што је тако много тужила за братом, кога је он био узео, па је претворио у кукавицу да кука до вијека“" (КАРАџић 1989: 64).

7 У широј словенској традицији порекло кукавице доводи се у везу и са другим гресима: похлепом, лажи, издајом, исмевањем Исуса или светитеља, кршењем забране рада на празник (ГурА 2005: 515).

8 „Ово кажи, ако опет дође: / Да с’ не бојим на св’јету никога [...] Док ми здраво утва златнокрила / У Дунају, водици студеној, / А у гори ува златноруна. / Не ћу нигда крепос изгубити, / Нити ћу ти нигда остарјети, / Ни бијела вила погрубјети“ (MH II, 20). 
јунака, генерално својствена епском певању. ${ }^{9}$ Најпознатији међу њима јесу варијанте о женидби Марковог сестрића („цвијет крепости“; KRSTIĆ 1984: $608)$, где младожења има задатак да преплива воду, савлада демонско биће и донесе чудесну биљку, како би добио руку цареве (банове) кћери, и велики круг варијаната о змији младожењи (KRSTÍ́ 1984: 628), који обухвата спектар метаморфоза:

Осим змије младожење у бајкама се чудесни облик јунака везује и за друге животиње: јежа, прасе, миша, бика итд. Када дође до измене номенклатуре, жена рађа ћерку - струк босиљка, а сходно таквој иницијалној ситуацији ток бајке се приближава мотивима о прогоњеним девојкама (рођеним из наранџе или каквог другог воћа). Према законитостима жанра, финални сегмент подразумева постојаност преображаја, те ће јунаци заувек остати у људском обличју. Истоветни су и обрти везани за ликове наглашено фантастичног порекла, те ће способности метаморфозе имати и испољавати виле, паунице, лабуд-девојке, ћерке дивова и вештица, али и девојке у кожи жабе. На крају наративног низа, као последица успостављеног склада и успешне иницијације, чудесни и људски супружници остају да срећно владају, заједно на једном од два света (САмАРџйA 2012: 16). ${ }^{10}$

И последњи поменути образац (змија / соко младожења ${ }^{11}$ ) и специфично епски арикулисане приче с мотивима метаморфозе упориште имају у латентно анималној природи, с једне стране, епских јунака - епонимних фигура и жижа према којима гравитирају основне координате епског модела света (просторни, анималистички, колорни, акциони код и др.) - а с друге стране, вила̄, које у маскулино центрираном систему какав је усмена епика, захваљујући демонској природи која их чини имуним на родну стратификацију, у неким аспектима представљају женски пандан јунака.

Епски систем конзистентно и у најширим координатама структурира модел простора, варирајући у непрегледном низу две основне просторне опозиције и два основна просторна правца - горе : доле (вертикала) и близу : далеко (хоризонтала) - успостављајући тим путем три основне координате: небо, земља, гора. Овим просторним одредницама стабилно су придружени животињски симболи - птица, змија и вук, који формулативно учествују у

${ }^{9}$ Епски јунаци често поседују змајевиту природу, за шта су еклатантни примери Змај Огњени Вук (Пешикан ЉуштАновић 2002; Перић 2008) и Бановић Секула, који се претвара у змију и сукобљава с турским царем претвореним у сокола.

10 Попис српских варијаната животињских невеста и младожења дат је у РАдуловић 2009: 205-206 (с компаративним освртом, стр. 209). За хрватски корпус (такође у компаративном контексту) погледати MARJANIĆ 2020. О метаморфозама у интернационалним оквирима детаљније у ВАсит 2008.

${ }^{11}$ Соко љуби ћерку краља од Стамбола: „Када једно јутро рано било, / Долијеће сокол птица сива, / Разбија јој врата од прозора / И ул’јеће у бијеле дворе, / Смеће с'себе ситне перушине, / Оста јунак ко на гори сунце. / И он љуби лијепе дјевојке“ (MH I, 35). 
структурирању фигуре епског јунака. Да би владао целим епским простором и био кадар да прелази границе (Лотман, Лихачов) и сукобљава се с бићима другачије природе (виле, џинови, јунаци каменити до половине, са змијама на срцу, са три главе и сл.) јунак мора делимично поседовати нељудску природу (ВАКотіс́ 1937: 13-14) и елементе који га повезују с екстремним просторним половима. Стога, у целини гледано, према епским јунацима гравитирају животиње које су маркери тих полова, и када је реч о атрибуцији, ${ }^{12}$ и када је реч о начину на који се оглашавају, ${ }^{13}$ и када је реч о њиховим белезима („Није чедо чеда каквано су: / Вучја шапа и орлово крило, / И змајево коло под пазуом“; CP, s. v. Змајогњени), и када је реч о помоћницима јунака (ПЕшиКАН ЉУШТАНОВИЋ 2002: 35-51; 78-80; СамарџијА 2012: 20, 35; ДЕлић 2019: 169-181):
а она се кучка домишљаше, те гвоздени сврда узимаше, те проврће деветоро вратах, те му кучка ране видијела, али Вука биљима видаху, змија њему биље доносаше, а вила му биље превијаше, а вук Вуку лиже ране љуте, цичи змија па под кам утече, а полеће у облаке вила, а завија у горицу вуче (CM 104).

Змијска (змајевита) и орнитоморфна димензија, које одређују фигуру јунака на најдубљој структурној равни, ${ }^{14}$ по свему судећи пресудно су утицале

\footnotetext{
12 Јунаци се именују соколима, „горским вуцима“, гујама: „Оно су ти све браћа рођена, / Оно су ти под каменом гује, / Којих жешћих у приморју нема“ (Вук III, 24). Више о томе у ПЕшикан-ЉуштАновић 2002: 35-51, 45-55; Перић 2008: 45-46; Делић 2019: 169-181.

13 Јунаци „кликћу“ као соколи („Кличе Ненад, како соко сиви“; Вук II, 16), завијају као вуци („До три мрка завијаше вука / у пазару на сред Сарајева, / то не била три крвава вука,/ но то била три горска хајдука“; СM 88) и пиште као гује („Пишти момче, како змија љута“; Вук II, 8).

14 У конкретном случају мисли се на фундаменталне поставке епског модела, који нас превасходно занима, али се о најдубљим стратусима може говорити и у дијахроном луку. Како показује Снежана Самарџија, мотив трансформације јунака у змију могао би имати упориште у најстаријим аграрним култовима - а у вези с менама природе и змијском регенерацијом путем одбацивања свлака: „Свакако је ’један од најупечатљивијих елемената церемоније годишњих доба драмски приказ смрти и поновног рађања месеца, годишњег доба, биљног света и божанстава која овим владају и управљају'. Истоветна је и 'логика идеја' промена у биолошком и социјалном животу јединке. Подударности сликовито и дословно значе 'променити кожу' (ВАн Генеп 2005: 210-212), а паралелизам се идеално згушњава и 'конкретизује' кроз сижејни склоп о јунаку-змији и одбацивању свлака. Али, када обред изгуби своју примарну сврху и прагматичност, прича о обреду може попримити различите обраде и значења. Драматизација древне идеје захтева не толико нову, колико
} 
на адоптирање бајковитих модела о змији / соколу младожењи, у којима се јунак који је дању змија, односно соко ноћу, у ложници, претвара у прелепог младића (,Тресну соко соколова крила, / Оста момак у танку кошуљу“; Вук VI, 4). Изостанак сукоба који би се потенцијално могао интерпретирати као епски, учинио је да епика преузимајући сижејни образац бајке акценат стави на табу „змајевитих белега“ (тајних моћи и тајне снаге) и на њихово угрожавање, познато епском певању у низу варијетета: од затапања „сабље са очима“ крвљу и спаљивања крила Момчиловом чудесном коњу Јабучилу (Вук II, 25), преко узимања „моћи од помоћи“ (такође везаном за круг песама о горостасном војводи), ${ }^{15}$ до одавања тајних помагача, као у претходно цитираној песми о смрти Змај Огњеног Вука (СМ 104). Отуда се у епским верзијама приче по правилу изневерава хепиенд бајке и јунак страда јер му мајка (понегде у сарадњи са снахом), у покушају да га лиши анималне димензије и трајно га преведе у људску заједницу, спаљује кошуљу (змијски свлак / кошуљицу) ${ }^{16}$ (МилошЕВИЋ ЂорЂЕВИЋ 1971: 76-111; САмАРџИјА 2012: 18-19; РАДУловић 2009: 206):
„Благо тебе, а и мене краље!
Ја се дигох на високу кулу,
На одаји ја отворих врата,
На јастуку од змије кошуља,
У душеку добар јунак спава,
Загрлио Призренку девојку;
Ја украдох од змије кошуљу,
Па ју турих на ту ватру живу.“
„Што је љубо, изела те змија!“
Потрчаше куле на висину,
Шта да виде? Чуда големога!
Мртав јунак у душеку лежи (Вук II, 12).

Традиција је, међутим, генерисала и специфично епски образац о метаморфима ослоњен на представу о змијској и птичјој природи јунака, и он је ексклузивно везан за Бановић Секулу. У овом сижејном моделу, чија су

посебно истакнуту кулминациону тачку. Мењајући угао посматрања и препознавања процеса, стилизације баладе и епике, свака на свој начин, дезинтегришу наслеђену матрицу. Уместо обредно-симболичке смрти вегетације, коју обавезно прати ускрснуће, сиже се 'зауставља' на насилном умирању младића“ (САмАРџијА 2012: 23).

15 „Поткради му моћи од помоћи / Са његовог јуначког рамена, / Драги камен из жута перчина, / Донеси га мени на Удбину“ (MH V, 209); биље у перчину „што за њ’ сабља прионут не може“ (СМ 147) и сл.

${ }^{16}$ Ретке су епске варијанте у којима мајчин потез не усмрћује јунака („Ах не лудуј, драго д’јете моје! / Што ће теби ситне перушине, / Што ће теби гора соколова? / Ти уживај б’јеле дворе твоје / И у двору миле мајке своје, / Миле мајке и госпође Фајке“; МН I, 35), што у основи реплицира ситуацију из бајке: „А мати и жена салете га: 'Па боље да си таки, и боље да си међу људима!' И тако га једва утишају. Кад то чује таст његов, одмах му још за свога живота преда царство, и тако он постане цар, те је царовао сретно до свога века“ (В 9). 
архаична упоришта идентификована у тотемизму, шаманској претворби јунака, те сукобу чаробњака метаморфа, ${ }^{17}$ Секула и турски цар трансформишу се у змију и сокола и у том облику се сукобљавају („Цар се Турски сазда у сокола, / Па одлеће небу под облаке, / Припази га Бановић Секула, / Па се сазда у шарену гују, / Па одлеће небу под облаке“; Вук II, 86). У напону два кодна система - с једне стране, просторног, у коме је соко, као метонимија врха, надређен змији, симболичком корелату подземља и дна (космичке) вертикале, и другог, условно речено „морфолошког“, који се односи на структуру епске фигуре и атрибуцију јунака (змајевитост) - генерише се трагичка позиција протагонисте, Бановић Секуле, који страда због кобног, али примереног и очекиваног избора његовог ујака Сибињанин Јанка да у одсудном моменту не стреља сокола, већ змију: „Зашт’ да стрељам сивога сокола, / Кад сам и сам рода соколова? / Волим стрељат’ змију шестокрилу“ (Вук II, 85).

Метаморфоза Бановић Секуле у певању о његовој смрти од стреле војводе Јанка једно је од најупечатљивијих сведочанстава о суштинској комплексности и поливалентности епских јунака, који се свођењем на само једну од компонената, било да је то људска природа, науштрб животињској (као у песмама о змији младожењи), или на само змијску или само птичју природу (као у овом кругу варијаната) - дезинтегришу и неминовно позиционирају у трагички процеп. Сукоб змије и птице несумњиво је један од базичних архетипова. ${ }^{18}$ У епском систему он је, међутим, привидан, јер су епски јунаци - попут змајева или Сфинге ${ }^{19}$ - фигуре синтезе, о чему, између осталог, сведочи већ и то што се Секула трансформише у „гују шестокрилу“, вичну лету и небеским висинама колико и соко.

По просторним доменима које обједињују путем атрибуције и сижејних функција, виле су умногоме пандан епском јунаку: владају водом (водарице виле, виле баждаркиње, ђумругџије виле и сл.), гором (,горске виле“, виле планинкиње, „од горице виле“ итд.) и небом (виле облакиње) (КАРАновић 2010: 289-298) и имају формално двојно - антропоморфно и анимално обличје. Левитирање виле између женског и птичјег лика и трансформација из једног у друго обличје познати су епском певању у низу варијетета:

Кад је било на истоку сунце,

А излети вила баждаркиња.

Не изл'јеће како женска глава, Него орле, тица страховита. Добро пази Краљевићу Марко, Откле орле тица излећела.

Вила се је у лов опремила (МH II, 20).

17 ЧАЈКАНОВИЋ 1994: 393-404; Лома 2002: 118, 129; ПЕРић 2007; РАДУЛОВИЋ 2005; Лукић 2016; Сувалџић 2014: 252-271; САмАРџијА 2012: 21-24.

${ }_{18}$ О томе детаљније у ДЕлић 2019: 13-41, где је дата и референтна литература.

19 Змајеви су комбинација рептила и летача, а доводе се у везу и са воденим животињама; Сфинга је у једној од најпознатијих интерпретација крилато биће с телом лава и главом човека. 
Но најмлађа полећела вила,

Полећела на бијела крила,

Она паде Мују више главе,

Па ми топле сузе пролијева,

Док Мујово прогорело лице;

Скочи Мујо, ка' да се помами,

Кад погледа, угледа ђевојку (Вук II, 11).

Долетише три тице голуба,

Па падоше на кулу Илијну.

То не била три тице голуба,

Вен то биле три бијеле виле,

А Мујине све три посестриме (MH IV, 40) и сл.

Овај систем представа (као и у случају комплексности епског јунака) генерисао је други тип специфично епске метаморфозе човека у животињу - онај који се препознаје по антологијској песми о смрти мајке Југовића. У иницијалном сегменту те варијанте и једној од чувенијих формула „чуда“ (Лома 2002: 21-35), мајка Југовића моли бога за „очи соколове“ и „крила лабудова“, како би савладала велику дистанцу и видела исход боја у коме су јој муж и девет синова:

Бога моли Југовића мајка, Да јој Бог да очи соколове И бијела крила лабудова, Да одлети над Косово равно, И да види девет Југовића И десетог стар-Југа Богдана. Што молила Бога домолила.

Бог јој дао очи соколове И бијела крила лабудова, Она лети над Косово равно, Мртви нађе девет Југовића И десетог стар-Југа Богдана (Вук II, 48).

Позивајући се на мотиве одсуства жаљења за мртима („И ту мајка тврда срдца била, / Да од срдца сузе не пустила“), огрешење о ритуалну праксу (узимање посмртних дарова са гроба) и, нарочито, на епилог песме у коме се мајка дословно надује и распадне („Надула се Југовића мајка, / Надула се, па се и распаде“"), Веселин Чајкановић је у мајци Југовића препознао фигуру виле (ЧАЈкАновић 1994: 94-109). На истом трагу је, с додатном аргументацијом, и Александар Лома. Порекло мотива метаморфозе - страног, како је већ речено, епској фантастици - објашњава се у конкретном случају демонским прототипом јунакиње и архаичним реликтима индоевропских представа о загробном свету ратника, којим је - судећи по Ломиној реконструкцији - доминирало женско демонско биће, оличено у нордијској митологији валкирама, а у нашој вилама (ЛомА 2002: 142). 
Трансформација мајке Југовића у птицу утицала је потом на лирику, која је мотив преузимала кад год је требало премостити удаљене хронотопе, углавном у вези с „погледом“ на стратишта:

Да су мени очи соколове,

Да ја видим гдјено војска пада,

Војска пада у сред Цариграда,

И убије три млада каплара.

Биели шатор један до другога,

Само један од зелене свиле;

Под њим сједи Стево момче младо.

Пуче пушка у сред поља равна,

И убије Стеву, момче младо -

(КUнаС̆ 968/1; УП. КUнаС̆ 968/2, MH VII, 495)

мада је лирика, захваљујући инерцији жанра, мотив лако пројектовала у интимне, љубавне сфере и скривену историју жена:

Бога моли Косовка девојка:

„Дај ми, Боже, што ми срце оће,

Дај ми, Боже, крила лабудова,

Дај ми, Боже, очи соколове,

Да одлетим на равно Косово,

Па да паднем у Милошеву ордију,

Да изберем момка према себе:

Што не пије вино и ракију,

Што не пуши дуван и бурмута.“

(Бов. 2, 367)
Бога моли севдали девојка:

„Дај ми, Боже, крила лабудова,

А и дај ми очи соколове,

Да прелетим Сарајеву у Босни,

Те да паднем у ладне меане,

Па да бирам драго према себе.“

(Бов. 2, 15)

Комбинација формула „очи соколове“ и „крила лабудова“ у датим круговима варијаната даје доста основа за претпоставку да је у конкретном случају реч о директном утицају песме из Вукове збирке на потоње певање, мада би у начелу логика усменог фолклора дозвољавала и могућност типолошких аналогија, узрокованих постојањем заједничког традицијског језгра које се сваки пут изнова активира у аналогним ситуацијама. На овакве процесе могле би указивати варијанте забележене на просторима који су били под мањим утицајем „канонских“ деветнаестовековних збирки (што поготово важи за лирику), с удаљеним варијацијама мотива, какав је, примера ради, трансформација мајке у голуба и њен лет до цариградске тамнице у којој јој је син девет година засужњен:

„Стори мь, Боже, престори

На н'акаква си гадина,

Вредом по свето да вьркам,

Дано Стојана намер'ь.“

Стори іь Господ, престори,

Стори іь сива гьльба. (СбНУ 42, стр. 159, бр. 143) 
3. БАЛАДИЧНЕ МЕТАМОРФОЗЕ. За разлику од бајки, које не оперишу категоријом греха ${ }^{20}$ и које са типским огрешењима усменог фолклора (какав је инцест), видели смо, не умеју да изађу на крај, усмена предања - чак и када у најбољој етиолошкој традицији, као делови космогонијског „великог наратива“ приповедају о пореклу ствари - опсесивно се баве феноменима греха и казне. Управо стога, она су и у контексту приче о метаморфозама далеко ближа усменој балади, која сопственим средствима „надзирања и кажњавања“ такође пропитује религијске, социјалне и етичке норме.

У начелу резервисана према фантастици, балада за њом интензивно посеже у домену који покрива и „маскира“ религија. Чудо се и у архаичном и у условно млађем - хришћанском - идеолошком кључу доживљава као вид еманације трансцендентног, па тиме и као реалност особеног типа. ${ }^{21}$ Са становишта религиозног човека, појава светаца и Божје интервенције у људском свету подједнако су вероватни и могући као и злочини међу сродницима, што је и мотиву метаморфозе човека у животињу под дејством „више силе“ широко отворило врата. Штавише, метаморфоза се показала једним од најефектнијих средстава опомене и кажњавања грешника - у два основна варијетета: грешници се трансформишу у змију или камен, или се неко од актера приче трансформише у животињу како би се на тај начин казнио грешник. Први случај карактеристичан је за велики круг песама о незахвалним синовима, чије огрешење о мајку 22 свеци кажњавају њиховим претварањем у камење и претварањем њихових љуба у змије или кукавице:

Девет сина девет каменова,

Девет снаа девет љути змија;

Пак се змије по камењу вију (Вук I, 204; уп. МН I, 38).

${ }^{20}$ Етика бајке је сасвим особеног типа; морални кодекс није исти за људска и нељудска бића. У вези с тим је и „проблем неморалног јунака“ (,Лоши поступци су лоши ако их јунак трпи, не ако их чини, њему је због остварења циља допуштено много тога неетичког; суштина природе јунака није у врлинама, него у магичној снази, често и лукавствима“). О томе видети у РАдуловић 2009: 65-128 (цитат је на стр. 109).

21 Дефинција фантастике зависи од дефиниције реалног и могућег, а оне су различите за различите социјалне групе; различита перспектива мора се предвидети за вернике, чији појмовни систем укључује и свето и профано (домени с различитим алетичким диспозицијама), и за заговорнике јединствене, профане онтологије (ДЕтелић 1989: 159-160; RYAN 1991: 40-41; Peruš́o 2018; Делит 2020). Уосталом, Петар Бакотић је још 1937. указивао на то да су и реално (ред) и фантастично (чудо) обједињени вишом структурном равни: „Па ни између закона реда и закона чуда (јер чуда су одступања од реда; догађаји супротни законима реда) не би смјело да буде супротности; а то је могуће ако закони чуда имају ограничену вриједност и ако заједно са законима реда потпадају под један опћи закон у којему се привидне супротности помирују“" (ВАкотіс́ 1937: 1).

22 Синови терају мајку од куће када остари и више не може да ради („Ој старице, стара наша мајка! / Ноге имаш, ходити не мореш, / Руке имаш, радити не мореш, / Очи имаш, гледати не мореш, / Сад нам, мајко, од користи ниси, / Сада ходи, куда теби драго!“; МН I, 38). 
Девет сина до девет камена, Девет снаха девет кукавица, Свака мужу над главом кукаше (Вук V, 218).

По истом обрасцу, под дејством клетве коју убијена супруга изриче на самрти, у камен и змију трансформишу се у словеначком фолклору муж и његова љубавница (SLP V/264/2; GoLEŽ KAUČ Ǐ 2012: 308). Клетва се по правилу активира и у наративима с темом непослушне кћери, било да је реч о предањима, где се ћерка која одбија да послуша очев налог претвара у змију која остаје да чува благо, ${ }^{23}$ било да је реч о баладама, где се под дејством мајчине клетве ћерка претвара у рибу:
„Моје дите Ловренац,
Ни ти дома сестрице.
Слала сам ју на воду
У кватерну недиљу, Ни ме хтила слушати,
Стала се је чешљати.
Љуто сам ју проклела
С оном мрзлом водицом:
Да у води пливала
Кај пловућа рибица“ (МН I, 9).

С друге стране, грешници се у усменом фолклору кажњавају и путем метаморфозе других, и то је простор где се емпатија и правда суспендују на рачун егземпла. Девојка коју против њене воље обљубљује хајдук-побратим претвара се у змију, да би се грешнику, као и Св. Недеља у сродном типу сижеа, овила око грла (ЈАСтр., стр. 146). ${ }^{24}$ Далеко је, ипак, познатији пример о злосрећном кумовању Грчића Манојла (KRSTÍ́ 1984: p. v. 169), који, кумујући „тананој Гркињи“ и „бијелој Влахињи“, поткупљен златом, мења женско чедо за мушко. ${ }^{25}$ Клетва мајке којој је замењено мушко дете, упркос чињеници да она женско дете дословно разбија о камен („Те развила оно

${ }^{23}$ Када грмечки краљ одлучи да под налетом снега напусти краљевство, његова најмлађа ћерка успротиви се јер јој је жао да остави благо. Отац је прокуне да се претвори у змију, која ће само о Ђурђевдану једном излазити, и ако тада сретне младића који ће је пољубити - да се врати у људско обличје и момку донесе благо (ПАЛАВЕСТРА 2003: 135-136). Ово је један од фреквентнијих мотива усмених предања о закопаном благу (уп. КАРАновић 1989: 80; САМАРџИЈА 2012: 25).

24 У змију се, на молбу упућену Св. Недељи, претвара и девојка која је потенцијална жртва инцеста: ,'Мили Боже и Неђељо млада, / Стварај мене у у змију шарену, / Да се ватим Ники око врата.' / Бог је драги за душу спримио, / Стварао је у змију шарену, / Ватила се Ники око врата“" (КАРАНОВић 1998: 13).

25 У песми не бива кажњена мајка која поткупљује кума и моли га да њено женско дете подметне другој жени, а њој да њено. Женско дете бива дословно разбијено о камен, и због тога више силе не интервенишу. 
чедо лудо; / Али није мушко, но ђевојка! / Шњом удари о камену станцу“), остварује се на начин који по суровости не заостаје за грчким митом. Манојлов син „промеће“ се у јагње, он га среће на путу, коље и једе, а по остацима баченим у зобницу препознаје га касније и мајка:

„Ја сам, љубо, јагње дочекао,

Убио га, па га испекао,

И од њега, љубо, обједова',

И плеће сам меса оставио;

Врзи руку у зобницу вранцу!“

Она бачи у зобницу руку,

Оно плеће меса дофатила,

Ал’ је оно од ђетета рука! (Вук II, 6)

4. С изузетком метаморфозе детета у јагње, које је у епику несумљиво ушло под утицајем хришћанског имагинаријума и наратива о жртвовању првенца (Аврамова жртва), епика, лирика и баладе знају за практично две трансформације - у птицу и змију. Кукавица је у лирици и предањима статус изборила захваљујући култу мртвих и обредној пракси жаљења. Соко и змија нашли су се ту по другачијој логици. Тежећи томе да буде народна „историја“, усмена епика је фантастику прихватила превасходно у домену хиперболе. Епски протагонисти надређени су људима „по степену“, не „по врсти“" (FRYE 1979: 45-46), иако њихови противници могу инклинирати модусу романсе (троглава бића, џинови, виле, каменити јунаци и сл.). Метаморфозе су се, отуда, прихватале само по изузетку, као вид Божје интервенције, која је са становишта хришћанске догме - неупитна. И то важи за епику, колико и за баладу, која је од пола фантастике и знатно удаљенија.

Иако су интерпретатори различитих провенијенција трансформацију у животиње везивали за холистичко егзистенцијално искуство и архетипе:

Postati žival ni samo beg iz človeškega $\mathrm{v}$ živalsko, ne gre za nazadovanje, kot se zdi v zgoraj omenjenih pesmih, je poskus razumeti žival, „biti žival, torej sem“" (DERRIDA 2002), se preleviti v žival in se nato vrniti v človeško telo. Če bi se navezali tudi na Junga (1995), gre pri preobrazbi iz človeškega v živalsko in nazaj, tudi za razumevanje ,živalske“ narave, s tem pa odpiranje človeškega pogleda na žival tako, da ta ni več spodaj, pač pa v isti ravnini kot človek, mu je enakovredna (Golež KaUČIČ 2012: 308) -

фолклорни корпус показује да се метаморфоза афирмише само уколико је из животиње у човека, свака друга негативно је конотирана и перцепирана као највећа могућа казна. Упркос широком и амбивалентном спектру симболичких значења које змија има у миту, фолклору и савременој култури, метаморфоза искључиво активира њен негативан аспект: „Метаморфоза је тек средство - слика којом треба да се подупру морални принципи колектива. У том смислу симболизација змије потпуно је окренута хтонским сферама, злу и смртоносном отрову“ (САмАРџијА 2012: 32). Ни спорадичне 
трансформације у животиње с неупитно позитивном симболиком - попут голуба - нису позитивне у укупном наративном скору: „Девет сина, девет каменова, / Девет снаа, девет ладни стена, / Два унука, два златна голуба, / Они лете од стене до стене“ (Вук I, 205). Податак да метаморфозе интегришу искуство људског и нељудског, не потиру чињеницу да се оне двоструко сагледавају, сходно смеру трансформација. Бајка с катарктичком радошћу претвара животиње у људе, али је супротан смер у свим фолклорним реализацијама везан за демонске димензије и за најсуровије казне, било да се у животиње трансформишу грешници, било да се у њих трансформишу невини, како би грешници били кажњени. У последњем случају, жртве су прибијене са два чавла - емпатије нема ни из емске ни из етске перспективе: актери приче жртвују их егземпла ради, слушаоци и читаоци приче централног наратива ради. ${ }^{26}$ Прича тих метаморфа остаје неиспричана. Трансформисани заувек у животиње, на силу обљубљени, искомадани и поједени, ови јунаци - и мушки и женски - остају ван сваког фокуса.

\section{ИЗВОРИ И ЦИТИРАНА ЛИТЕРАТУРА}

Бов. 2: Наровна књижевносӣ Срба на Косову и Мейохији. Лирске иессме II. Владимир Бован (прир.). Косовска Митровица - Приштина: Панорама, 2013.

В: Срйске нарояне йрийовијейке. Скупио их Вук Стеф. Караџић. Мирослав Пантић (прир.). Београд: Просвета, 1988.

ВАн Генеп, Арнолд. Обреgи йрелаза: систиемайско изучавање рийуала. Београд: Српска књижевна задруга, 2005.

ВАсић, Данијела. Суние и мач: јайански мийови у делу Кођики. Београд: Рад, 2008. Вук I-IV: Срйске народне ӥјесме I-IV. Скупио их Вук Стеф. Караџић. Београд: Просвета, 1975-1988.

Вук V: Срйске наровне ӥјесме. Скупио их Вук Стеф. Караџић. Књиїа йейа у којој су различне женске ӥјесме. Љубомир Стојановић (прир.). Биоград: Државно издање, 1898.

Вук VI-IX: Срйске нарояне ӥјесме VI-IX. Скупио их Вук Стеф. Караџић. Љубомир Стојановић (прир.). Београд: Државно издање, 1899-1902.

ГурА, Александар. Симболика живоиииња у словенској нарояној йраяииији. Београд: Бримо - Логос - Александрија, 2005.

26 У необично постављеној, али суштински добро заснованој класификацији Петра Бакотића (једној од неколиких), понуђеној пре више од осамдесет година (1937: 41), која је водила рачуна о становишту жртвованих ликова, ове метаморфозе именоване су „бескорисним“: „Чуда су (као што су наведена) бескорисна или су корисна. У питању је да ли више силе делују да заштите праведника, или му чак надокнаде штету коју су му насилници учинили, да га обилато награде за његову праведност, или пак да од тих сила нема лично никакве материјалне користи, него оне дјелују да заштите морални поредак сам.“ 
ДЕлић, Лидија. Змија, а сриеска. Концейӣуализаиија у усменом фолклору. Вишеград: Андрићев институт, 2019.

ДЕлић, Лидија. Јагње ђурђевско. Пригушена фантастика жртве. Дејан Ајдачић, Бошко Сувајџић (ур.). Савремена срйска фолклористиика 8. Словенски фолклор и књижевна фанйасииика: зборник раяова. Београд: Удружење фолклориста Србије - Комисија за фолклористику Међународног комитета слависта - Универзитетска библиотека „Светозар Марковић“; Лозница: Центар за културу „Вук Караџић“, 2020, 9-25.

ДЕтелић, Мирјана. Поетика фантастичног простора у српској народној бајци. Предраг Палавестра (ур.). Срйска фанииасииика-найирирояно и фанииасииччно у срииској књижевносиии. Београд: САНУ, 1989, 159-168.

ДЕтелић, Мирјана. Урок и невесйа: йоеииика ейске формуле. Београд: Балканолошки институт; Крагујевац: Центар за научна истраживања САНУ, 1996.

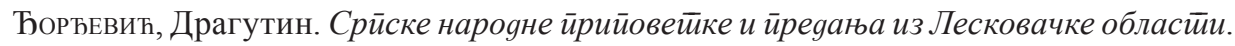
Нада Милошевић Ђорђевић (прир.). Београд: САНУ, 1988.

ЂоръЕвић, Тихомир. Прироgа у веровању и йреgању нащеїа нароga I. СЕЗб 71 (1958): $1-319$.

ЗлАтковић, Драгољуб. Прийовейке и йреgања из Пиройской краја. Део II - йреgања. Београд: ИКУМ, Пирот: Дом културе, 2007.

ЈАСтр.: Ястребов, Иван Степанович. Обычаи и пъсни турецкихь Сербовь: (вь Призрънъ, Ипекъ, Моравъ и Дибрђ. С. Петербургь: Типографія В. С. Балашева, 1886.

КАРАновић, Зоја. Анйолойија срйске лирско-ейске усмене йоезије. Нови Сад: Светови, 1998.

КАРАновић, Зоја. Небеска невесйа. Београд: Друштво за српски језик и књижевност Србије, 2010.

КАРАџић, Вук Стефановић. Оиичсаније Србије. Београд: БИГЗ, 1989.

ЛомА, Александар. Пракосово. Словенски и иняоевройски корени срйске ейике. Крагујевац: Центар за научна истраживања САНУ и Универзитета у Крагујевцу, Београд: Балканолошки институт САНУ, 2002.

Лукић, Славица. Ейска биоїрафија Бановић Секуле у јужнословенском кониеексӣу. Докторска дисертација. Филолошки факултет у Београду, 2016.

МАрковић Снежана. Прийовет̄ке и йреgања из Левча. Нови зайиси. Београд: Чигоја штампа, Крагујевац: Центар за научна истраживања САНУ, 2004.

Милошевић-Ђоръевић, Нада. Зајеgничка иеемайско-сижејна основа сриискохрвайских неистиоријских ейских иеесама и йрозне йраяииије. Београд: Филолошки факултет, 1971.

ПАЛАвестрА, Влајко. Хисииоријска усмена йреgања из Босне и Хериейовине. Београд: Српски генеалошки центар, 2003.

ПЕрић, Драгољуб. Песма „Секула се у змију претворио“као епски сиже о шаманској борби чаробњака (реторика жанра). Зоја Карановић (ур.). Зборник синхронијско и gијахронијско изучавање врсйа у срйској књижевностии. Нови Сад: Филозофски факултет - Дневник, 2007, 47-55. 
ПЕрић, Драгољуб. Териоморфни јунации словенске еииике. Београд: Београдска књига, 2008.

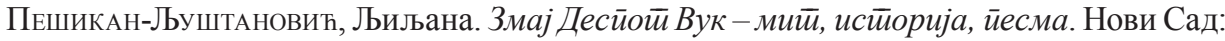
Матица српска, 2002.

РАдуловић, Немања. Две метаморфозе у нашој епици. Свеш̄ речи XI/19-20 (2005): 40-42.

РАдуловић, Немања. Слика свет̄а у срӣским нарояним бајкама. Београд: ИКУМ, 2009.

Самарџија, Снежана. Биоїрафије ейских јунака. Београд: Друштво за српски језик и књижевност Србије, 2008.

САмарџијА, Снежана. Ко се крије испод змијског свлака? Метаморфозе у жанровском систему. Мирјана Детелић, Лидија Делић (ур.). Гује и јакрейи: књижевности, кулйура. Београд: Балканолошки институт, 2012, 13-41.

САмарџијА, Снежана. Облици усмене прозе. Београд: Службени гласник, 2011.

СбНУ: Сборник за нарояни умойворения наука и книжнина, от. кн. 27. Сборник за нарояни умойворения и нароgойис. МНП (от кн. ХІХ изд. Българското книжовно дружество, а от кн. XXVII - БАН). София, 1889 -.

СМ: Сима Милутиновић Сарајлија. Пјеванија ирноіорска и хериеіовачка. Добрило Аранитовић (прир.). Никшић: Унирекс, 1990. [Лајпциг, 1837]

CP: Караџић, Вук Стефановић. Срйски рјечник (1852) I, А-П. Сабрана дела Вука Караџића, књига једанаеста (1). Јован Кашић (прир.). Београд: Просвета, 1986.

Сувајџи, Бошко. Орао се вијаще. Преявуковски зайиси срйске усмене йоезије. Ниш: Филозофски факултет, Београд: Филолошки факултет, 2014.

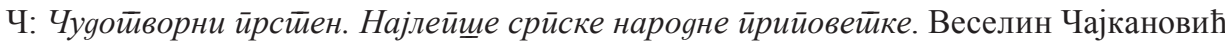
(прир.). Ниш: Просвета, 2002.

ЧАлКАновић, Веселин. Сӣуgије из срӣске релиі̄ије и фолклора 1910-1924. Сабрана дела из српске религије и митологије. Књига прва. Београд: СКЗ - БИГЗ - Просвета - Партенон, 1994.

BАкоті́́, Petar. Pojav čuda i zakon reda u narodnoj književnosti. ZNŽOJS 31/1 (1937): $1-66$.

Derrida, Jaques. The Animal That Therefore I am. Critical Inquiry 28/2 (2002): 369-418. Frye, Northrop. Anatomija kritike. Četiri eseja. Zagreb: Naprijed, 1979.

Golež KaUČIČ, Marjetka. „Fantje so goljufivi kot škorpijoni“. Kače in škorpijoni v Slovenski folklori in poeziji. Мирјана Детелић, Лидија Делић (ур.). Гује и јакрейu:

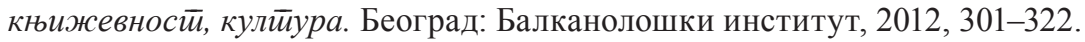

Jung, K. G. Arhetipi, kolektivno nezavedno, sinhroniciteta. Maribor: Katedra, 1995.

Karanović, Zoja. Zakopano blago - život i priča. Novi Sad: Bratstvo-Jedinstvo - Institut za jugoslovenske književnosti i opštu književnost Filozofskog fakulteta, 1989.

KRSTIĆ, Branislav. Indeks motiva narodnih pesama balkanskih Slovena. Beograd: SANU, 1984.

KUHAČ, Franjo. Južno-slovjenske narodne popievke III. Zagreb: Tiskara i litografija C. Albrehta, 1880. 
MARJANIĆ, Suzana. Babina Bilka i bajke o mladoženjama/mladama životinjama: kontekst - Slavonija. Radovi Zavoda za znanstveni i umjetnički rad u Požegi 9. Požega: Zavod za znanstveni i umjetnički rad u Požegi; Zagreb: HAZU, 2020, 143-160.

MH I-IX: Hrvatske narodne pjesme. Zagreb: Matica hrvatska, 1890-1940.

PERUŠKo, Tatjana. U labirintu teorija. O fantastici i fantastičnom. Zagreb: Hrvatska sveučilišna naklada, 2018.

Prop, Vladimir Jakovljevič. Historijski korijeni bajke. Sarajevo: Svjetlost, 1990.

Ryan, Marie-Lore. Possible Worlds, Artificial Intelligence, and Narrative Theory. Indiana University Bloomington \& Indianapolis Press, 1991.

SLP V: Štrekelj, Karel. Slovenske narodne pesmi I-IV. Ljubljana: Slovenska matica, 1898-1914.

Lidija D. Delić

MAN'S METAMORPHOSIS INTO AN ANIMAL

Logic of transformation in oral folklore

\section{Summary}

On the basis of the material from Serbian oral folklore, the paper illustrates the logic of the modification of man into an animal in a whole range of genres, from the fairytale and tale, to the ballad and epic, based on the particular types of fantasy, strategies of conceptualization and pragmatics of the text. The paper follows the directions of transformation and the connection of metamorphosis and sin (miracle, emanation of the transcendental), which is a foundation for the reconstruction of the position and "use" of animal in the anthropocentric model of the world.

Institut za književnost i umetnost

Kralja Milana 2, Beograd

lidija.boskovic@gmail.com 